811.163.41'373.611

81'1:165

https://doi.org/10.18485/sj.2020.25.1.12

ДРАГАНА Д. ВЕЉКОВИЋ СТАНКОВИЋ

Универзитет у Београду

Филолошки факултет
Оригинални научни рад

Примљен: 15. 10. 2019.

Прихваћен: 15. 01. 2020.

\title{
О ХИПОКОРИСТИЧНИМ ЗНАЧЕЮИМА АПЕЛАТИВА С НЕГАТИВНИМ ЕВАЛУТИВНИМ ПРЕДЗНАКОМ ТВОРБЕНЕ И/ИЛИ ЛЕКСИЧКЕ ОСНОВЕ У СРПСКОМ ЈЕЗИКУ**
}

У раду се испитује динамика евалутивног система који, као кохерентан а асиметричан континуум, у српском језику почива на садејству и интерференцији двају, примарно физичких концепата - димензије и удаљености, тј. емотивне дистание. Разматрање семантичких исхода хипокористичке творбе апелатива с негативним предзнаком творбене и/или лексичке основе, разврстаних у шест тематских група, води следећим закључцима: (а) семе добра (драго, блиско), као стожери позитивних вредности које језик и његови говорници чувају, стабилне су и - за разлику од семе лоше, која има различите варијетете - неподложне реинтерпретацији; (б) евалутивна енантиосемија је последица потенцијала реинтерпретације семе лоше и/или могућности сагледавања једне појаве или особине из двеју различитих, опречних перспектива (нпр. злища); (в) хипокоризација негативних основа представља тенденцију да се позитивни ареал амелиорацијом прошири, чиме се - на рачун социјално и индивидуално маркираних негативитета - штити домен врлине.

Кључне речи: евалутивни систем, српски језик, творба речи, маламелиоративи, семантичка деривација, хипокористици, пејоративи, евалутивна енантиосемија.

*draganavs@yahoo.com

** Овај рад је написан у оквиру пројекта 178006 Српски језик и његови ресурси, који финансира Министарство просвете, науке и технолошког развоја Републике Србије. 


\section{1. УВОД}

1.0. Поларизација доброг и лошег (зла), као егзистенцијално и културно важних концепата људске заједнице, кључни је механизам у формирању и структурисању вредносне парадигме која управља свим појединачним и колективним стремљењима и делањима човека. Ова два комплексна концепта окосница су и развође бројних супротности (светло - тама, правда - неправда, љубав - мржња и др.) које одувек искушавају човекову мисао и дух, збуњујући их својом разноликошћу и преплитањем. Сукобљавање али и укрштање ових концепата налазимо и у језику, а један од модуса тог „сукоба” огледа се у супротстављености пејоратива и хипокористика, па и самих процеса пејорације и хипокоризације ${ }^{1}$, тј. настанка евалутивно заснованих значења која се на најшире постављеном аксиолошко-емотивном плану обично посматрају као непомирљиви антагонисти. На први поглед опречност је несумњива, посебно када почива на творбено заснованом диспаритету сема велико и мало, које својим антонимним односом подстичу квалитативну, тј. вредносну дихотомију. Међутим, посматрајући ова два евалутивна правца као целину, односно као узајамно условљене, компатибилне сегменте истог система, а не као непомирљиве полове (премда се оцена испољава позитивним или негативним предзнаком), запажамо да испод површинске подвојености постоји доста широк простор сусрета и прожимања вредносно супротстављених елемената значења, који нам дозвољава да евалутивне творенице (али не само њих, већ и просте речи и творенице које имају хип. или пеј. значење) посматрамо као део афилијативног континуума.

1.1. Централна питања овог рада су следећа: Ако хипокоризацију посматрамо као аксиолошко-емотивну промоцију позитивних, пожељних квалитета, откуда да таква промоција обухвата и лексеме које денотирају неку негативну појаву, својство или носиоца тог својства? Која негативна својства се прихватају? Зашто? Да ли је реч о одобравању, толерисању или неуједначеном вредновању негативитета? Може ли негативно истовремено бити и позитивно, тј. схваћено као такво? Како говорници српског језика поимају и категоризују негативитете?

Одговоре на ова питања потражићемо у описним речницима српског језика (РМС, РСАНУ, РСЈ), а примере ексцерпиране из њих, којима придружујемо и оне преузете из електронског Корпуса савременог српског језика (СрпКор2013), груписаћемо с обзиром на тип негативитета (недостатка / мане)

${ }^{1}$ Познато је да је деминуција један од најзначајних изворишта хипокористичности, мада у оквиру деривације постоји и круг суфикса којима се граде само хипокористици, па се зато говори и о хипокористичној творби (исп. Окука 2008: 40). У евалутивном домену изузетно су бројни антропоними, јер се њима изражава наклоност према другој особи. У овом раду, међутим, разматрамо само хипокористичка значења апелатива. 
сигнализован значењем основе. Свака од издвојених група биће посматрана из угла хипокористичке амелиорације, а циљ рада је утврђивање става и степена толеранције говорне заједнице у односу на поједне негативитете / недостатке, те одређивање утицаја хипокоризације на круг апелативних лексема у српском језику за које смо, у овом раду, а с обзиром на њихову семантику и експресивну обојеност, употребили термин маламелиоративи (nomina malum ameliorativum). Методолошки приступ грађи и семантичке анализе биће засновани на когнитивном схватању деминуцијије, аугментације, хипокоризације и пејорације као компатибилних творбено-семантичких процеса на којима почива евалутивни систем. У основи прва два процеса је концепт функционалног ВАРИРАњА КВАНТИТЕТА, а два потоња карактерише ВАРИРАњЕ (АКСИОЛОШКЕ И/ИЛИ АФЕКТИВНЕ) ДИСТАНЦЕ. ${ }^{2}$

\section{2. ХИПОКОРИСТИЧКО-АМЕЛИОРАТИВНИ ПОМАЦИ НЕГАТИВНИХ ЛЕКСИЧКИХ И/ИЛИ ТВОРБЕНИХ ОСНОВА}

2.0. Питање како настају хипокористична значења повезано је с вредносним системом говорника одређеног језика, јер се, уопштетно узевши, хипокористичност може схватити као зближавање и афективно присвајање, тј. увођење у повлашћени аксиолошки и емотивни простор свега што је процењено као вредно, блиско па отуда и драго. Евалуација, међутим, обједињује не само деминуцију и аугментацију, већ и хипокоризацију и пејорацију, па ове процесе и резултате њихове треба посматрати као узајамно условљене и обједињене у оквиру аксиолошког система говорника једног језика. Пошто деминуцијом и аугментацијом управљају семе квантитета (мало / велико), а хипокоризацијом и пејорацијом афективне семе блиско - неблиско и прихваћено - неприхваћено, тј. афилијација и дистанцираност (блиско, мило / одбојно, немило), схваћене као (позитиван или негативан) квалитет (хип. или пеј.), у оквиру аксиолошко-емотивне оцене, пресудну улогу има поимање дистанще. ${ }^{3}$

\footnotetext{
${ }^{2}$ Свакодневно искуство с конкретнопредметним реалијама уверава нас да су ова два концепта тесно повезана, па тако блискост, а са њом и позитивна оцена, корелира с афилијацијом, док је емотивна дистанца аналогна физичком, па и осећајном дистанцирању (уп. проксемична експресија).

${ }^{3}$ Човеков емотивни простор концептуализује се преко метафора блискости и дистанце (ЕМОЦИОНАЛНА БЛИСКОСТ ЈЕ ФИЗИЧКА БЛИСКОСТ, ЕМОЦИОНАЛНА ДИСТАНЦА ЈЕ ФИЗИЧКА ДИСТАНЦА, ОДСУСТВО ЕМОЦИОНАЛНЕ РЕАКЦИЈЕ ЈЕСТЕ ОДСУСТВО БЛИСКОСТИ, уп. Они су блиски / присни / нераздвојни пријатељи. Увек је био хладан и далек, никоме није дозвољавао да му се приближи. и сл.), а блискост је такође изворни домен метафора сличности, солидарности, компромиса и подршке (исп. Лејкоф и др. ${ }^{2} 1991:$ 155-157). Природно је да се као средиште емоционалности одређују срие и душа (Кликовац 2004: 207, 211), а све оно што се доживљава као мило, пожељно, добро настоји се приближити емотивном центру. Отуда се хипокористици употребљавају као маркери редукције дистанце, а пејоративи као означиоци
} 
Смањивање дистанце води хипокоризацији, а повећање пејорацији; тако видимо да је атенуација на квантитативној оси аналогна специфичној атенуацији на квалитативној оси, укратко - и у једном и у другом домену значењима управљају концепти величине (интензитета) и просторне удаљености (МАЛО / МИЛО И БЛИСКО ЈЕ ДОБРО - ДеМ. и ХИП.; МАЛО / НЕМИЛО И НЕБЛИСКО ЈЕ ЛОШЕ - Дем. и пеј.; ВЕЛИКО / НЕМИЛО И НЕБЛИСКО ЈЕ ЛОШЕ - аугм. и пеј.; ВЕЛИКО / МИЛО И БЛИСКО ЈЕ ДОБРО - аугм. и хиП. /уп. лаудација/). Ово су очекивани и типични исходи квантитативно-квалитативних укрштања, па се зато најчешће узимају као достатни за разумевање односа унутар евалутивног система речи субјективне оцене, а симетричну сапостављеност њихову могли бисмо представити следећом схемом:

Схема 1. Идеализован схематски приказ типичних бинарних односа и исхода укрштаја квантитативно-квалитативних домена у оквиру евалутивног система у српском језику.

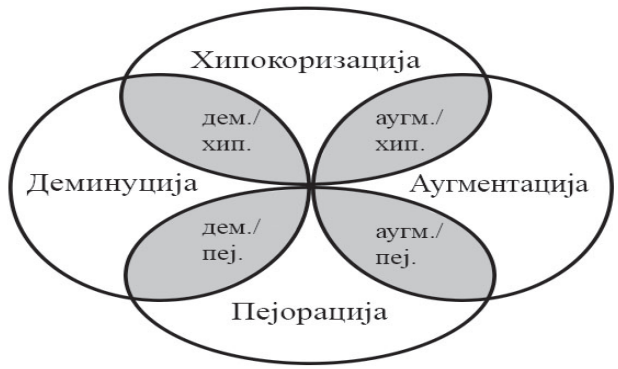

2.1. Оваква схема може послужити као једноставан, али упрошћен графички приказ семантизације евалутива, међутим, пошто су односи између кореспондентних поља знатно комплекснији и динамичнији, таква схема не одражава сасвим тачно сложеност семантичких релација (мада може послужити као пријемчиво средство визуелизације творбено-семантичких односа у основношколској настави српског језика). Разлог томе видимо у чињеници да се дихотомија асиолошко-емотивног простора не може посматрати као статична, јер се њена поља активно и продуктивно прожимају, оформљујући спојеве негативних основа са деминутивно-хипокористичким суфиксима (уп. гадурица, глупачища, злоћко и др.), а има и хипокористично интонираних пејоратива и аугментатива (уп. парипино стара, магаре моје лепо и сл.), код којих се став наклоности препознаје у контексту.

њеног повећања, тј. удаљавања из повлашћеног сегмента емотивног ареала. Међутим, то не значи да домен пејорације није обухваћен емотивно-аксиолошким системом, већ само да припада његовом негативном делу. 
Због контраста негативитета мотивне речи с амелиоративним творбеним елементом, код многих лексема које припадају овом кругу запажамо склоност развијању евалутивне енантиосемије. Њима су, по правилу, именовани носиоци својстава или понашања која се од стране припадника језичке заједнице сматрају непожељнима, али - захваљујући повољној процени (особе) - неповољно значење се релативизује, обично уз слабију или израженију хипокоризацију. Очито је, дакле, да атенуација не делује само на квантитативном, већ и на квалитативном плану, и то као умерена или израженија амелиорација пејоратива. Све то показује да поделе не могу бити строге, јер семантичка деривација и живи творбени процеси унутар евалутивног система указују на континуитет варирања и преклапања наизглед неспојивих семантичких обележја, а њихово здруживање у семантици исте лексеме резултира евалутивном енантиосемијом. Те комплексне односе покушали смо приказати следећом схемом, у којој сивом бојом означена поља обележавају позицију амелиоративних апелатива с негативним значењем основе, тј. домен хипокористичне атенуације пејоратива и других сродних „хибридних” семантизација:

Схема 2. Приказ динамике и комплементарних односа у оквиру евалутивног система српског језика, као и позиције аксиолошко-емотивних „хибридних” семантизација. ${ }^{4}$

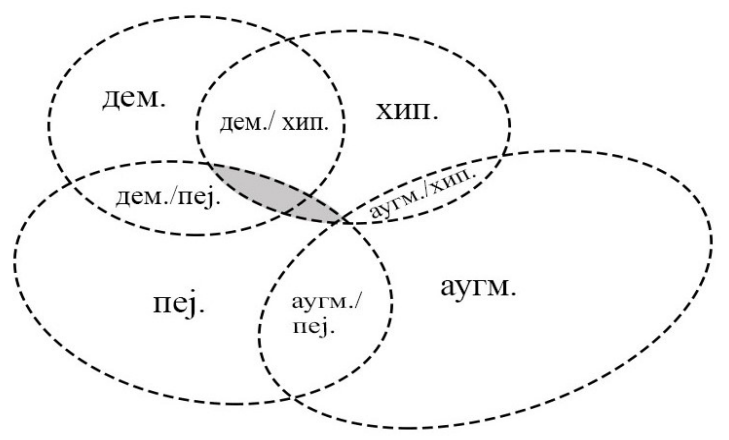

${ }^{4}$ Тумачење схеме 2. Приказ посебних семантичких поља испрекиданом линијом сигнализује њихову динамику и енергију проширивања и укрштања. Наиме, свако од четири главна поља, иако овде - због немогућности геометријске транспозиције апстрактног - није приказано једнаком повшином, има једнаку могућност ширења. Преклапања појединих поља (дем. / хип. и аугм. / пеј.) нису идентична, па тако треба имати у виду да аугментација у већој мери привлачи пејорацију но што деминуција привлачи хипокоризацију (исп. 3.1). Коса црта обележава квантитативно-квалитативне творбено-семантичке укрштаје, а затамњена зона у пресеку домена дем., хип. и пеј., као и хип. и пеј. означава област амелиоразиције негативних основа, у којој се - код невеликог броја лексема - реализује и потенцијал евалутивне енантиосемије, тј. развијања позитивног и негативног емотивно-аксиолошког значења у оквиру истог полисемантичког поља. 
2.1.1. Главно питање тиче се разрешења аксиолошког противуречја у српском језику, па се зато, поред дистрибуције и прихватљивости негативитета и/или какве нежељене, неповољне појаве, особине, понашања и др., у раду бавимо и условима њихове прихватљивости, који указују на лингвокултуролошку условљеност евалутивних помака у српском језику.

Евалутивна поларизација у српском језику јавља се и код домаћих (простих) и код страних речи (без обзира на фреквенцију), нпр. угурсуз, лопов, алчак, галијот, лутка. ${ }^{5}$ Евалутивна енантиосемија у таквим примерима настаје применом битно различитих параметара оцене, при чему се издваја једна сема и реинтерпретацијом - у складу с променом оцењивачке перспективе - добија супротан евалутивни презнак. Тако је код прве четири лексеме негативитет (лош, неваљао; уп. фн 5) реинтерпретиран, па се „лоше X” посматра као „прихватљиво X”: „способан за лоше/неваљалство, онај који чини штогод лоше” $\rightarrow$ „способан за наивнија, мања неваљалства”, дакле $\rightarrow$ окретан, живахан, виталан (духом); док код лексеме лутка евалутивни контраст настаје на темељу супротстављених интерпретација денотата: „предмет (налик лепој женској особи) намењен за игру” - хип. : „особа којом се други могу играти (манипулисати њом)" - пеј.

2.1.2. Ипак, то није једини начин настанка енантиосемичних односа, па ћемо се зато, имајући у виду значај ове појаве за тему којом се бавимо, кратко задржати на проблематици за коју посебан интерес показују изучаваоци словенских, али и других језика. Енантиосеми, као „јанусовске речи”, како их назива Макартур (1996: 494), према мишљењу неких лингвиста нису ретке. Такав став деле Ривелис (2008) и Шмељов (2012). Супротстављена значења унутар једне лексеме Ривелис пореди са фокусирањем једног дела геометријског тела (коцке) у различитим положајима, те енантиосеме сматра

${ }^{5}$ РМС бележи: угу̀рсуз тур. а. неваљалаи; зао, опак човек. б. обешењак, мангуи, лола, влаголан, спадало. - Мора бити да је неко вабио вашке [псе]. - А има и угурсуза па дувају у кључ. Лаз. Л. ло́по̄в маџ. 1. а. онај који краде, лупеж, крадљиваи. - И лопов и варалица је био. Шен. Лопове један, показаћу ти ја како се жене краду! Трифк. б. нитков. - Читав је свијет један велики лопов. Донч. 2. хип. лола, препредељьк, мангуn. - А Пава Циганин - лопов - нагнуо се ... па му свира у само ухо. Ивак. Станите, лопови једни! - раздрагано се бранио момак од те необуздане и разигране псеће љубави. Ћоn.

а̀лчак тур. 1. лопов, варалица, крадљиваи. 2. хип. враголан, обемењак, мангуn. - Нити хаје, алчак, што за њоме црко. Шант.

галйјот тал. покр. 1. ист. а. бродар, морнар, лађар. б. осуђеник који ради на галији. 2. а. хип. обешењак. - Ја сам Кико, знате, онај ... мали галијот Кико. Мат. б. пеј. невалалац. - Проклети анархисти! Лупежи! Галијоти! Мат.

лӱтка 1. људска (обично женска) фигура која служи као дечја играчка, кројачки модел и сл.; фиг. хип. женска особа лепог лика. - Дражесна је та мала лутка! Нам. 2. име одмила. - Срце ми се начетворо цепа, све због тебе, лутко моја лепа. Леск. 3. пеј. особа без вредности која само фигурира на неком месту; особа којом неко други управља. - Ослободимо се свега што од нас чини безвољне лутке. $M-O$. 
концептима (са заједничким именитељем) који дозвољавају „двострука читања" (Ривелис 2008: 164). А. Шмељов, који наводи чак десет уобичајених механизама настанка енантиосемичних значења (2012: 837), енантиосемију сматра регуларном појавом заснованом на неким општим принципима људске когниције и комуникације (Шмељов 2012: 838). Р. Н. Викторивна, из уже перспективе, говори о деминутивној енантиосемији у украјинском језику, поткрепљујући овај термин запажањем да деминутиви могу имати и позитиван и негативан евалутивни предзнак, а да антонимну семантичко-функционалну природу дугују концепту малог (Викторивна 2017: 168-169). Енантиосемичност ауторка сматра универзалним својством категорије деминутивности у свим језицима света (2017: 171).

Имајући у виду научна разматрања о енантиосемији (Макартур 1996; Шипка 2002; Драгићевић 2007; Ривелис 2008; Махмутова 2009; Федорова 2011; Шмељов 2012; Викторивна 2017), ми семантички потенцијал евалутива не посматрамо само из тог угла, мада енантиосемија карактерише узак круг амелиорираних пејоратива. Што се пак тиче деминутивне енантиосемије (Викторивна 2017), сматрамо да оваквом уопштавању нема места када је у питању српски језик, тим пре што би се - по аналогији - тада морала постулирати и аугментативна енантиосемија, а самим тим бисмо (а) сузили семантички потенцијал евалутива у целини, одрекли им способност варирања значења и (б) оштро га поларизовали, што, с обзиром на наше досадашње увиде у ову област, ни у ком случају не би одговарало семантици умањеница у српском језику. Најзад, овакав приступ не може објаснити значења мешовите, „сиве зоне" евалуације (исп. Схема 2), тј. значењске структуре апелатива који обједињују негативно и позитивно, а које Викторивна скупно и без диференцијације сврстава у еуфемизме (2017: 171-172); још мање бисмо могли разјаснити изостанак обрнутог споја (изразито позитивна основа + аугм. суфикс, нпр. * срећетина). ${ }^{6}$ Значења означена као ир.[онична] могу, с обзиром на природу ироније, неке проучаваоце навести на идеју о енантиосемичности умањеница, али такав став нема упориште у српском језику, јер је у њему деминуција само један од извора пејоративности.

Закључујемо да се - уз неспорне сродности - особености евалутивних система у словенским језицима разликују. Што се тиче енантиосемије у кругу лексема које у овом раду разматрамо, ту појаву ћемо посматрати као концепт чији елементи дозвољавају супротне семантичке интерпретације. У многим случајевима, имајући у виду доминацију мање или више изражених недостатака, девијација, мана и сл., код евалутива с негативном основом у питању

${ }^{6}$ Нпр. премда РСАНУ бележи им. мудрачина, и то само као аугм. и пеј. (>мудрац), нема им. попут *срећетина и сл. са хип. значењем (већ само срећица, срцуленце, сунашце и сл.), а таквом творбено-семантичком обликовању опиру се и други супстантиви с наглашено позитивом семантиком (нпр. радост, милина, љубав, светлост и сл.). 
су аксиолошки еластични концепти код којих се енантиосемија заснива на потенцијалу реинтерпретације негативитета. Пошто је супротстављеност значења запажена и код позајмљеница, најпре наводимо примере који илуструју поларизацију значења у овом лексичком кругу (уп. фн 5):

(1) А зашто бих, да вас питам? Да тражим себи угурсуза кога ћу пре тога да волим. Да после не умем да га се отресем?! (СрпКор 2013, Политика, 14. 5. 2001).

(2) ...и Ана ће сама да се увери да је била у заблуди ако је мислила да је тај гитариста, тај мали лопов, човек њеног живота... (СрпКор 2013, Милисав Савић, Одбрана вароши од вештица, у: Ујак наше вароши, Београд, СК3, 1977).

(3) Кад би код дирека, маши се руком за јабуку, али алчаци обесили јабуку хотимице високо, па је не дохвати први пут, него се мораде заскочити... (СрпКор2013, Иво Андрић, Пут Алије Берзелеза).

(4) Обиђите један ђир по Котору, седите крај карампане (чесме), можда угледате неког од которских ориђинала, галиота или шкерца и са њим проћакулате (СрпКор2013, Политика, 26. 11. 2010).

Како примери из електронског Корпуса савременог српског језика показују, ове лексеме живе су у говору ${ }^{7}$, као и у књижевном језику, а поред хипокористичних, често имају и шаљива значења. Има, међутим, и оних чије је хипокристичке реализације тешко наћи у савременом језику, па су тако, нпр., им. маторац и маторка, осим код старијих писаца (5), доста ретке са хип. значењем, а то показује и РС $(2011)^{8}$, док се, с друге стране, под утицајем жаргона примећује детериорација ових именица у разговорном и књижевном језику (6):

(5) Кода, као права маторка, тресе забринуто главом (СрпКор2013, Исидора Секулић, Хроника паланачког гробља, у: Антологија српске кюижевности, Учитељски факултет).

7 Од поменутих експресива са хип. значењем свакако је најређа им. галйјот (мада РСАНУ бележи и галѝјотић, галѝјоче, галѝјочић), за коју у СрпКор2013, као и у слободној интернет претрази налазимо свега неколико потврда, и то искључиво у неправилном облику, без J (*галиот м. галијот), највероватније под утицајем неписања слова Ј у позицији између вокала И и О (уп. гл. прид. радио, прионуо; им. радио, милион и сл.). То показује да се код речи које се ретко употребљавају губи језичко осећање које упућује на мотивацију (па се основа /им. галија/ и јединачни суфикс -от не разазнају; Клајн 2002: 220); самим тим се у питање доводи морфолошка правилност, а у усменом изражавању и ортоепска норма.

${ }^{8} \mathrm{PMC}$ : мато́рац а. матор човек. б. хип. онај који је одрастао, велик (о дечаку), маторко. - Нуто мога маторца како ми ради! ... кликну Миона радосно. Глиш. РСАНУ: 1. в. хип. одрастао, велики дечак; дечак који се понаша као одрастао човек, прерано сазрео, стармали дечак. У PCЈ им. матораи означена је квалификаторима разг. и експр. (а), док хип. - уз поменуто значење (РМС б; РСАНУ 1. в) изостаје, а аналогна семантизација им. маторка обележена је као разг. и фам. 
(6) Кљакави маторци одлазе у кухињу да чисте кромпир, репу... (СрпКор2013, Антоније Исаковић, Трен 2 : Казивања Чеперку, Београд, Просвета, 1983).

2.1.3. С обзиром на гравитирање семантичких садржаја основе и усмереност према номинацији људских слабости, недостатака и мана, хипокористике апелатива који су значењски и/или творбено везани за негативни аксиолошки пол разврстали смо у шест тематских група: (1) физичке мане и естетски недостаци, (2) когнитивне слабости, (3) карактерни недостаци, (4) моралне аномалије, (5) социјална неуклопљеност и маргинализованост, (6) неповољне појаве и реалије с негативном конотацијом.

2.2. ФИЗИЧКЕ МАНЕ И ЕСТЕТСКИ НЕДОСТАЦИ. Прву групу чИне nomina atributiva мотивисана придевима који денотирају урођену или стечену ману по којој се неко препознаје и именује (ше́na, ћópa, ћóna, ћéла, тр́бо, méno, мýua; pýњa, чýna, бýuа и др.). За разлику од деривата на -аци и -ица, ове творенице имају изражену експресивност; по правилу су изведене типичним хипокористичким суфиксима (-a/-o) којима се негативна придевска мотивација добрим делом неутралише. Међутим, само посезање за основом која апострофира какву физичку или естетску ману показује да недостатак или оно што се као такво види није посве занемарено, већ је - као мање битно - потиснуто у други план, док је носилац такве особине прихваћен с наклоношћу. Општа семантичка формула „човек с недостатком X” модификована је творбено уведеном (позитивном) афективном семом, која се код других хипокористика препознаје као блиско $X$ (нпр. уjа, прија, меда и сл.), док се овде реализује као „блиско и (стога) прихватљьив $X$ ”. Хипокоризација примарно није управљена према основом експонираној мани, већ према њеном носиоцу.

Поред хипокористичне обојености, већина ових твореница - зависно од контекста - може имати и иронично значење, што је у описним речницима сигнализовано паралелним навођењем квалификатора (хип. и ир.). Вероватно је управо ова чињеница утицала на ставове неких проучавалаца који деноминале овог типа сврставају у хипокористике (нпр. рођа, побра, стрика и сл.), а деадјективе у пејоративе (исп. Бјелановић 2006: 9-13). Позивајући се на Бабића

${ }^{9}$ Ж. Бјелановић наводи низове деноминалних (дје́до, дје́mо, póђо, стри́ко, та́jо и др.) и деадјективних деривата (чу́по, ће́ло, ћóро, ћóсо, го́љо и сл.), изведених суфиксом -о и закључује: „Budući da su ovi motivirani kakvim nepoželjnim svojstvom označenika, značenjski se razlikuju od onih tvorenih od imenica i značenje im je sasvim oprečno po konotacijskom predznaku. Tako se i pokraćeničnim tvorbenim načinom, jednako kao i svim drugim načinima tvorbe, ostvaruju tvorenice koje pripadaju različitim značenjskim kategorijama" (Бјелановић 2006: 11). Ипак, аутор запажа да оваква груба подела не само да не може бити безостатно прихваћена, већ има очите слабости, те додаје: „Povelik je broj tvorenica kojima se značenje očituje tek u kontekstu, jezičnom ili izvanjezičnom. Tako se npr. tvorenica klémpo značenjem razlikuje označava li kakvu domaću životinju ili označava kakvu osobu klempavih ušiju. Između tvorenica koje su po značenjskoj jasnoći na krajnjim dijelovima značenjske ljestvice nalaze se u neprekinutom slijedu nemjerljivih razlika skupine tvorenica 
(1986), који за ове творенице каже да су „stilski obilježene, većinom kao blaže ili jače pogrdnice" (1986: 256), Бјелановић их заправо разврстава према основи, не водећи рачуна о модификаторском потенцијалу хипокористичних суфикса, нити претежно пејоративних (нпр. на -оља), па ни о оним неутралним (нпр. на -ац). Аутор, међутим, запажа постојање варијетета у оквиру евалутивног континуума, те констатује да све творенице овог типа „nije moguće jednoznačno opisati i svrstati ih u semantičke sustave" (Бјелановић 2006: 11; исп. фн 9).

Реч је заправо о нетипичним хипокористицима који припадају рубној сфери позитивне оцене, док њихова основа с обележјем неког негативитета гравитира детериоративима, а неке мотивне речи уистину јесу пејоративи. Отуда они често бивају иронично и подсмешљиво интонирани, али у разговорном и књижевном језику постоји доста потврда њихове употребе у хипокористичним контекстима, па све ове чињенице поткрепљују целовитост, али и шароликост и неуједначеност евалутивног система, који, као што смо већ нагласили, није строго поларизован, већ се у њему параметри оцене укрштају, што природно резултира различитом семантиком и позиционираношћу типичних и атипичних евалутива.

Језичка економија огледа се и у овом сегменту, па тако, захваљујући атракцији разноврсних основа и евалутивних суфикса, природно настају спојеви који се не могу једнозначно одредити, већ их ваља посматрати не само као творбене деривате, већ и као деривате смисла. Зато је вероватно најтеже дефинисати значења твореница које припадају зони вишеструких укрштаја квантитативног и квалитативног поља (исп. Схема 2, фн 4). Рекло би се да је томе узрок умерена, не сасвим потиснута детериорација, док се снажнији аксиолошки контраст препознаје код хипокоризације пејоративне основе (нпр. грдииа); парадоксално, управо на оваквим примерима хипокоризација негативитета и њен учинак лакше се идентификују и разумеју. Међу хипористицима овог типа, махом изведеним суфиксима - $a /$ - $о$ и -ко, издвајају се неке основе с високом атракцијом, а типичан пример је творба хипокористика са значењем „дебељушкаста, пуначка особа”, чија бројност указује на толерисање ове

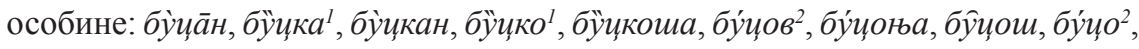
буцика ${ }^{l}$, дйћка, дйћко (отуда и надимци: Буца, Буцика, Дућа и сл.).

2.3. КОГНИТИВНЕ СЛАБОСТИ. У когнитивном домену хипокоризација знатно ублажава значење основе (уп. глӥпко, тӱпко, ћуре́нце и сл.), уз наклоност према особи којој се нелуцидност и неразборитост приписују, чак и када је у питању семантичка деривација (као нпр. код им. луђакиња; РМС: фиг. хип. Смири се, смири, моја дражесна луђакињо! Ков. А.). Изведенице обухваћене овом групом карактерише миноризација мане исказане основом (лудовчић

u kojih značenjski signali za identifikaciju i kvalifikaciju stoje po jačini naboja u posebnom odnosu. Takve nije moguće jednoznačno opisati i svrstati ih u semantičke sustave” (Бјелановић 2006: 11). 
> лу̀до̄в - глуп човек, будала, лудак; глупа̀нчић, гу̀шчица, блу̀нииа > блу́на, бле́ка - блесавко, блесавица; будала), понекад и њено занемаривање у корист наглашавања симпатија и топлине (буда̀лища, звр́ка ${ }^{2}>$ звркан покр. онај који је звркаст, луда, бена), јер се добар део ових лексема употребљава са циљем појачања перлокутивног ефекта и реализовања кооперативног принципа у оквиру интерперсоналних односа (Грајс 1975:45-47). Облик деминутива тако постаје творбено обележје амелиорације којим се донекле може неутралисати и израженија пејорација мотивне речи (уп. мазго̀вче, мазго̀вчић > ма̀зго̄в РСАНУ: 2. фиг. пеј. а. тврдоглав, својеглав, задрт човек. б. неразуман, глуп човек, будала, глупак. в. лењ, нерадан човек, ленштина; вуцибатина. 3. фиг. пеј. звекан, клипан).

Већина хипокористичних реализација у описним речницима потврђена је у дијалогу, и то у облику вокатива. ${ }^{10}$ Такви примери показују да се хипокористици овог типа примарно везују за комуникацију лицем у лице, поглавито у ситуацијама у којима се код саговорника подразумевају међусобна наклоност и блискост, због чега им се прагматичка функција може упоредити с употребом аугментатива али и простих речи, којима се, под сличним околностима, неутралише пејоративност (нпр. лудо једна; парипино стара и сл.). Штавише, рекло би се да се у оба случаја управо избором таквих речи или основа, када је реч о хипокористицима, доброхотност и интимност наглашавају, а често је тако и с речима из претходне групе (уп. т. 2.2), јер приликом увођења у афективну сферу супротног предзнака негативно значење основе, по свему судећи, има значајну улогу у појачавању експресивности, било да се ради о толерисању каквог неозбиљног понашања, било да је реч о наглашено срдачном, присном обраћању или сл. Експресивност расте управно пропорционално с удаљеношћу значења основе (или денотативног значења неизведне речи) од сфере позитивног, доброг, па се тако присност емфатички наглашава контрастом између семантике и комуникативне функције апелатива:

(7) „Како ти лупа срце, лудо једна”, рекла ми је тренутак касније, стављајући ухо на моје груди (СрпКор2013, М. В. Љоса, Авантуре неваљале девојчище, Београд, Лагуна, 2008).

(8) Аха, немаш обичај, узречица ти је: коњу један! Шта кажеш, и теби је тако говорила мајка из милоште. Баш фино (СрпКор2013, Политика, 10. 12. 2010).

${ }^{10} \mathrm{PMC}$ : буда̀лица ж и м дем. и хип. од будала. - Шимек, будалицо мајчина. Гор. лӱдица ж и м дем. и хип. од луда. - Лудице мала, та ти си ми се једини свиђао! Сим. лудо̀вчић м дем. и хип. од лудов. - Што ме зовете кад ме се бојите, момчићи лудовчићи! Брл. (лудов = лудак, будала). звр́ка² ${ }^{2}$ хип. и ир. од звркан, звркаста особа. - Радо, зврко, ко ти је рекао да човеку избацујеш ствари из куће? Пази је само! Ћоп. ћуре́нце дем. и хип. од ћуре. ћуิрчица ж дем. и хип. од ћурка. - Ћурчица мамина - изговори жена и пољуби дете. Дом. 
(9) Ах, пусти ме, молим те. - Не, лудице моја, - тепао јој је Милош, и љубио ју је у врат и лице. - Шта ти је данас? Што се бојиш? (СрпКор2013, Милутин Ускоковић, Дошљаци, Београд, Народно дело, 1932).

(10) Ти би, дакле, мени за љубав на све пошао, а? Па зар си ти збиља, будалице моја, хтео сутра да се убијеш? (СрпКор2013, Ф. М. Достојевски, Браћа Карамазови, електронска верзија).

Зоолексеме чија се фигуративна значења употребљавају за именовање неразборите, неумне особе умањивањем теже мењају предзнак оцене, па најчешће чувају детериоративну сему, осим када се користе у обраћању драгим особама; у тим случајевима могу се посматрати као евалутивни енантиосеми. Премда ова значења (хип., пеј., па и ир.) у речницима нису квалификаторима увек обележена, она се у контекстима јасно препознају (уп. гӱшчииа, гуишче и сл.). ${ }^{11}$

2.4. КАРАКТЕРНИ НЕДОСТАЦИ. Већина карактерних недостатака подложних хипокоризацији могла би се назвати слабостима, а најбројније су лексеме изведене суфиксом -ко (плачко, завезанко, смотанко, уображенко, гордељивко и др.). Овој групи припадају и деминутивна образовања, нпр. лажовчић, ленчугица, згубиданчић и сл., од којих прве две наши описни речници не бележе, али их налазимо у разговорном језику, и то као жива образовања, којима се могу реализовати презрива и иронична (11), али и хипокористична значења $(12,13)$, док је потоња у РСАНУ означена као дем. и хип. од згубидан, мада, као и претходне, може у одговарајућим контекстима варирати експресивну обојеност $(15,16)$, а с тим у вези и супротне евалутивне предзнаке:

${ }^{11}$ РСАНУ: гу̀шчица дем. и хип. од гуска. - Укратко, била је лијепа, занимљива сеоска гушчица и њу је Дамјан узео ... за жену (Мил. В., СКГл 10, 411). Није хтио да и посљедња гушчица модре крви вријеђа ... његову супругу (Ђал. 11, 133). Још Јелкица понешто и зна, а ја сам права гушчица (Тар. 1, 42). гӱшче фиг. 1) хип. [Илија деци]: Ево ме, гушчићи моји! (Војн. И. 6, 57). 2) погрд. глупавко. - Ја никад нећу бити тако гушче | Да слушам нагон (Стеф. Св. 11, 141). Неки пејоративи хипокоризацијом не негирају значење основе, већ се управо њој захваљујући промовишу у тзв. заштитна имена (уп. гадић), док код основа чија мотивна реч поседује и погрдно значење (магаре, магаренце), сема младо у фигуративној семантизацији подстиче хипокористично значење (уп. Џурафски 1996: 533; 541-553) којим се готово сасвим потире детериоративна семантика. Тако у секундарном значењу им. магаре (РСАНУ: 2. фиг. а. погрд. онај који тешко схвата, тупавко (при обраћању неком млађем, обично детету). б. еуф. у тепању, нежном обраћању некоме (обично уз реч „моје”) у значењу: драго моје, слатко моје. - Јованка се кмези и плаче. Де, немој плакати, магаре моје, проћи ће те то до ујутру (Самок. 4,127$)$.) запажамо енанатиосемичну подвојеност која произилази, с једне стране, из повезивања с фиг. значењем зоосема (магараи), док се, на другој страни, увођењем у емотивну сферу, детериорација неутрализује позитивним ставом према субјекту, па се - уз наглашавање посесивности (моје), као маркер безостатног прихватања - преводи у хипокористик, наглашеном афилијацијом лишен пејоративности (уп. „драго моје, слатко моје”). Афилијација је, дакле, не само један од услова творбене хипокоризације, већ је често и покретач семантичке деривације која резулатира секундарним значењима уз неутрализацију примарне пејоративности. 
(11) Колико се сећам, овај лажовчић је био трајно банован (с правом) (forum.b92.net, 1. 12. 2014).

(12) Пинокио је био лакомислен и лажовчић, а сваки пут када би рекао неку неистину нос би му порастао... (korisnaknjiga.com, 20. 5. 2019).

(13) Ова наша Ева, мала ленчугица, гледа како да шмугне кад треба нешто да одради (forum.krstarica.com; 20. 10. 2019).

(14) Јао, лењивко један! Док му родбина ради, ово магаре само ужива! (espreso.rs; 17. 6. 2019).

(15) Чуо бих познати глас како ме доброћудно опомиње: „Шта радиш, згубиданчићу?” (С. Тишма, Пролеће, одломак из прозе Quattro stagioni; polja.rs).

(16) То су згубиданчићи, не знају куда ће са својом енергијом коју им је Бог дао (slobodnaevropa.org; 16. 3. 2006).

Премда се неке особине којима су поједини носиоци маркирани, с обзиром на културолошку парадигму носилаца српског језика, сматрају већим (нпр. гордост, као један од смртних грехова), а неке мањим недостацима (плачљивост, смотаност и сл.), извесно је да је већина њих социјално непожељна (лењост, лажљивост и др.), па се стога именовање оваквим лексемама сматара поузданим начином персоналне дисквалификације. Таква дисквалификација, ипак, може бити ублажена или обеснажена деминутивним обликом који сигнализује симпатију према појединцу, али се не односи на прихватање недостатка, па се отуда концептулизује као „прихваћеност особе упркос недостатку X”, а не као „прихватање недостатка X (одређене особе)”. Шаљива интонација и хумористични контексти, као и код осталих твореница добијених суфиксом -ко, доприносе релативизацији негативитета.

2.5. МОРАЛНЕ АНОМАЛИЈЕ. Хипокористичност етичког круга више од осталих показује могућност приближавања аксиолошких крајности лош / зао / немио - добар / мио / близак. Најбројније су именице из деривационог гнезда зло (зло́ја, зло̀ћан, злӧћко, зли́ша, зло̀ћан, злӧћкища), мада има и других супстантива с изразито негативним значењем основе чије увођење у домен позитивног, рекли бисмо, пре свега потврђује свест о неминовности лошег, па с тим у складу и тежњу према његовој минимизацији и отклањању, нарочито када су у питању тзв. заштитна имена или ословљавања „против урока” (гад, гадура и сл.). ${ }^{12}$

${ }^{12}$ Хипокоризација се огледа и у антропонимији, посебно у надимцима (уп. Векица >Bесна, Живкица $>$ Живка и сл.), но Ж. Требјешанин наводи велику групу тзв. заштитних имена (уп. негативне основе) која се деци дају „против урока”: „Таква имена су: Грд, Грдан, Грдман, Грдоња, Гнусан, Грубадин, Грубаш, Грубиша, Груја, Гад, Грозо и сл. На први поглед, чини се врло чудним како могу родитељи својој малој, тек рођеној деци давати тако ружна имена. Разлог за то јесте свакако тај што родитељи стрепе за живот вољеног детета, те управо стога дају детету неко од имена која су мрска како би га оставиле на миру вештице, бабице и друга зла бића и уроци 
Творбени спој позитивног (евалутивног предзнака) и негативног (експонираног мотивном речју, тј. творбеном основом) треба посматрати из шире аксиолошке перспективе. Најпре ваља имати на уму да се сам поларитет добро - зло јавља захваљујући паралелном постојању оба појма, јер би у одсуству једне компоненте било немогуће говорити о вредносном систему, пошто недостатак контраста логички укида сваку разноликост и тиме обесмишљава препознавање и промоцију једног као ваљаног а другог као лошег. Друга околност, која се непосредно надовезује на чињеницу о неопходности контраста, односи се на природу добра и зла. Добро је одраз хармоније, сагласја између човекових жеља, потреба, тежњи и реалитета; такво сагласје препознајемо као идеално стање које не покреће, већ осујећује акцију (јер би га она могла нарушити), зато је - за разлику од зла - добро монохромно и пасивно. Уколико би постојали искључиво добро и врлина, неиздиференцираност добра би сама по себи укинула не само потребу за рангирањем, већ и вредност добра као таквог. Зато зло егзистира као condicio sine qua non аксиологије. ${ }^{13}$

Пошто су људске слабости храна злу, које се поима као НЕПРИЈАТЕЉ У ЧОВЕКУ и (СПОЉАШЬА) НЕПРИЈАТЕЉСКА СИЛА (тј. оПасност /По егзистенцију/ којом човек не влада), то се тематски типови који се односе на непожељне карактерне особине (2.4), моралне аномалије (2.5) и неповољне појаве (2.7) показују повезанима на дубљем, онтолошком нивоу, јер својом негативном енергијом изазивају потребу за језичким „припитомљавањем”, па се зато хипокоризација ових домена може посматрати обједињено - као средство експресивне атенуације круцијалних негативитета. Атенуација се, дакле, не испољава само на квантитативној оси (дем.), већ и на квалитативној (хип.), иако се снага зла понекад очитује у афирмативним значењима лексема које денотирају злог човека (исп. РСАНУ: злиияа, 2. а, б). ${ }^{14}$

који нападају баш оно што је лепо, драго и мило" (Требјешанин 1991 : 97). У РСАНУ читамо: гӓд 1. а. погрд. особа која заслужује презир, осуду или изазива одвратност, гађење (понекад у шали и тепању). - Ви сте гад, - викала је Оливера. - Загорчавате ми последње часове (Бој. Р. 2, 13). б. етн. покр. реч од урока која се говори детету. - Ако „баба” овом приликом погледа дете, онда пљуне ... и рекне му: „гад” ... да га не би урочила (Миј. С. 3, 3). 3. (обично зб.) животиње (ређе поједина од юих) које код човека изазивају одвратност и гађење (ирви, буве, ваши, мишеви, жабе, змије и сл.); гамад.

${ }^{13}$ Зло је ослонац контраста, па без њега ни добро не би могло бити препознато као такво; поред тога, зло постоји у безбројним варијацијама, јер претња добру може бити већа или мања (интензитет), ближа или даља (просторно-временски каузалитет), стварна или претпостављена (процена реалности), препознатљива или у извесној мери маскирана итд. Речју, суштина и појавност зла поседује знатно виши степен креативности и динамичности, па томе захваљујући подстиче и суптилнију категоризацију добра (схваћеног као врлог, вредног, пожељног, жељеног X).

${ }^{14}$ РСАНУ: злйща 1. а. зао, опак човек. 2. покр. а. велики, неустрашив јунак. - То су биле све саме злице, кероји (Ускоци, Станић Мил.). б. врло вредна, отресита особа, способна да изврши и најтеже задатке, прегалач. - Ти си мајчина злица (И.). злӧћкица хип. од злоћа (б). - Не дирај ти њу, злоћкице моја (Ков. Анд. 1, 165). хӱљица м и ж дем. и хип. од хуљь. петља̀нче дем. и хип. од петља́нац [петља́нац а. онај који петља, сплеткари, вара и лаже, непостојан човек, 
С обзиром на то да језик одражава вредности говорног колектива, засноване на културним мерилима и социјално формираној перспективи процене, која је обликована традицијом и заједничким искуством, аксиолошки судари препознати код твореница чија основа и/или мотивна реч означавају штогод лоше, непожељно, зазорно, друштвено проскрибовано и сл. одражавају способност колектива да створи еластичну вредносну перспективу. Јер, као што се у појединим случајевима, па и издвојеним групама амелиоративних лексема види, хипокористични „огртач”, било да је творбено препознатљив (нпр. као типично деминутивни или хип. суфикс), или није (у случајевима семантичке деривације) ретко када може поништити негативитет семантичке (лексичке) подлоге, већ га најчешће релативизује и/или интерпретира као „делимично или условно прихватљиво”. У питању, дакле, није потирање лошег по себи, па ни исказивање наклоности према непожељном, већ афективна амелиорација негативног коју бисмо могли разумети преко метафоре ДРАГО / БЛИСКО / ПОЖЕљНО УПРКОС НЕГАТИВНОМ СВОЈСТВУ Х. Из овога следи да Хипокоризација негативних основа почива на каузалитету степена и околности прихватљивости, а тај каузалитет, као и узроци прихватања различити су у посебним групама маламелиоративних лексема. ${ }^{15}$

\section{6. СОЦИЈАЛНА НЕУКЛОПЉЕНОСТ И МАРГИНАЛИЗОВАНОСТ.} Социјална неуклопљеност, посебно код деце и младих, не посматра се увек с осудом, по свему судећи зато што је очекивана, па се именице као што су неваљалко, неваљалица, мангупче, мангупчић, нестачче, обешењачић и сл. јављају као израз разумевања за непокорно, па и ветрогоњасто понашање. Међутим, када је реч о одраслим особама, оваква евалуација добија друкчији смер (обично подругљив и ироничан). У питању је маркирање одступања од општеприхваћеног понашања које је у одређеном узрасту очекивано, те се

сплеткар, смутљивац. б. онај који нешто неорганизовано, с муком ради, петљь. - Он је прави петљанац, дрибла лопту непотребно, па је изгуби или погрешно дода (Ред.)]. бестијица хип. од бестија. - Него ви, ви ... плава бестијице, златна корњачице, ви, колико сте их још залуђивали тим ађеоским погледом, а? (Петр. В. 9, 63). [бестија 2. фиг. особа са животињским, рђавим инстинктима. б. неваљалаи, битанга, обешењак. - Јест бестија, али је свакоме мио, јер је детиње душе! (Мат. 8, 54). 3. фам. (у грубом обраћағу) будала, бена. - Мучи кћери, муч бестијо! (НП, БB 1891, 314)].

${ }^{15}$ Примера ради, узроци прихватљивости хипокористика изведених од основа које упућују на негативне физичке мане и естетске недостатке друкчији су у односу на оне чија основа маркира социјалну неуклопљеност. Код првих се указује на прихватање и позитиван афективни став према особи, и то упркос каквој (физичкој или физиолошкој) мани коју поседује, па се тиме показује да је особа прихваћена / драга каква јесте (у целини, упркос мани X), док је у случају социјалне неуклопљености у првом плану амелиорација, тј. модус благонаклоног става према облику непожељног понашања (мангупче - мангуплук, неваљалко - наваљалство и сл.), а тек потом заузимање таквог става према ономе ко се сматра експонентом неког непримереног понашања. 
може толерисати, док се код старијих сматра непримереним. ${ }^{16}$ Слично је и код хипокористицима обележене социјалне подређености и маргиналзације, јер ту у многим случајевима пресудну улогу има афективни моменат, тј. емпатија и сажаљење (јӓдничић и ја̀дничић, подера́нко, ту́чь /хип. од ту̀ца̄к онај који се потуиа по свету живећи од милостиње, просјак/ и сл.). Социјалну маргинализованост, као облик друштвене неуклопљености, карактерише мање или више изражена невољност. Када је укљученост појединца у ову групу одређена спољашњим околностима, над којима особа нема контролу нити одговорност (уп. спу̀рjа̄нче > спу̀рјан, спу̀рјанин - ванбрачно дете; сирота́нче и сл.), хипокоризација је подстакнута емпатијом, утолико израженијом уколико је могућност појединца да се одупре негативном мања. Зато је припадност овом кругу амелиоратива обележена изразитијом хипокоризацијом, и у односу на негативно својство, и у односу на носиоце тог негативног својства.

Најслабији учинак хипокоризације у овој групи запажамо код им. геàчић, гéja / гéjo (хип. од гёа̄к 1. прост, неваспитан човек, простак), јер је код ових деривата сачувана изражена пејоративност основе (РСАНУ: Али да то ће опанчарче и гејачић умети толико је обрлатити ... томе се није надао нико (Маш. 1, 148).).

\section{7. НЕПОВОЉНЕ ПОЈАВЕ И РЕАЛИЈЕ С НЕГАТИВНОМ КОНОТА-} ЦИЈОМ. Међу негативним појавама већина је оних на које човек не може утицати, међутим, и о њима се понекад говори с помирљивошћу, па се хипокористицима, рекло би се, ублажава неминовност трпљења и страховања. Од четири подгрупе које смо издвојили у оквиру ове невелике тематске скупине издвајају се лоши судбински исходи и физиолошка стања која угрожавају човека ${ }^{17}$ :

(а) негативна осећања: жало̀сиа, је́дак, мӱчица;

(б) лоша физиолошка стања: гла́дак, гла́йа (> глад), бôчица (> бољка), ватри́штиница (> ватруштина), гро́jа (> грозница);

(в) лоше околности и трагични исходи: ко́бак, ко́пцุа (>коб), нѐсрећица, смйиа;

(г) негативни резултати људског деловања: свӓђица, клеттвица, ӧсветицุа.

${ }^{16}$ Ексцентричност је, дакле, овде условно толерисана, па се са симпатијом посматра једино уколико је усклађена са незрелошћу и још неформираном свешћу о неопходности поштовања општих правила примереног понашања, а детериорација је производ успостављања лимита између недораслог и одраслог, чиме се изражавају друштвена очекивања у погледу стицања свести о успостављању добре мере између захтева средине, динамике стасавања и индивидуације.

${ }^{17}$ РСАНУ: мўчица дем. и хип. од мйка ${ }^{I}$ - Није лака ствар кренути на пут ... има ту потешких мучица које све ваља премучити (Мил. М. Ђ. 20, 3). Збогом тврда земљо оранице, муко, мучице и весеље моје (Горан 3,61$)$. нѐсрећица дем. и хип. од несрећа. - Умре ли сиромах, вуче звонар полагано, дође ли несрећица на какова богатијег, вуче свом снагом и жељезо удара у шињу (Павешић Ф., ХК 14, 156). Ти, зумбулићу, несрећице моја, што си ми почео венути! (Мат. $9,22)$. 
У електронском Корпусу савременог српског језика (СрпКор2013) нисмо нашли примере ових апелатива с апстрактним значењем, већ само један с фигуративним (17), док се у колоквијалном језику може чути и мукица (=jадник):

(17) Ево га сад мишар како се обрушава. Подигне се да ухвати залет па се стушти. Нека мала длакава несрећица дочекала је свој крај, све с кидањем и пиштањем (СрпКор2013, Нил Грифитс, Патрљак, Београд, Фабрика књига, 2006).

(18) Он, мукица, кад би прочитао те коментаре, никад више ни о коме реч не би рекао... (republika.rs, 21. 8. 2017).

Од реалија с негативном конотацијом издвајају се лексеме мотивисане именицама гроб, гробниияа и гробље: гро̀бић, гре́бак (> покр. грёб), гро̀баи, гроба́mач; грӧбничица, гробља́шие, гробље́нще. Међутим, ови, као и претходно наведени евалутиви - осим као поетизми - изузетно ретко се употребљавају. Ипак, потврде о атракцији тих основа, које налазимо у речницима (пре свега у РСАНУ), говоре у прилог потреби за умилостивљењем табуираних појава, пре свега оних које представљају највећу егзистенцијалну претњу (глад, болест, коб, несрећа, смрт), а потом и благонаклоности према месту вечног почивка, чијим се увођењем у афективну сферу показују емоције и изражава поштовање према преминулима (уп. СМ 2001, s.v. гроб, гробље).

\section{3. ЗАКЉУЧНЕ НАПОМЕНЕ}

3.1. Број лексема у нашим описним речницима које су обележене квалификатором хип.[окористично] или као реч одмила знатно је мањи од речи које се као хипокористици употребљавају у разговорном језику, па и у књижевноуметничком стилу, док су остале нијансе хипокористичности, као посебни случајеви амелиорације, подведене под шаљь.[иво], еуф. [емистички], експр.[есивно], или је пак деминутиву ознака хипокористичне реализације остала ускраћена због недостатка афективно израженијег контекста у корпусу. Анализа четири тома PCAНУ (књ. III, VII, XI, XVI) већ је показала да су хипокористична значења знатно слабије повезана с деминуцијом неголи пејорација с аугментацијом (исп. Вељковић Станковић 2011: 61-65).

3.2. Творбена атракција основе којом се именује штогод непожељно израженија је (а) уколико се недостатак сматра ефемерним (буца) или (б) ако је потреба за неутрализацијом негативитета већа (уп. зло; табуирана лексика), (в) а хипокоризација и афилијација су наглашеније код лексема којима се именују естетски, когнитивни недостаци и социјална неуклопљеност. Хипокористици и хипокористичка творба могу се сматрати етноспецифичном карактеристиком српском језика јер се користе као модус лексичких апотропеја (тзв. заштитне речи) којим се умилостивљују и одвраћају различите злости. То на особен 
начин потврђује и енантиосемна усмереност семантичке деривације код примарно негативних евалутива (уп. гад/uћ/ и сл.).

3.3. Евалутивна енантиосемија, као могућност реализације супротних емотивно-аксиолошких предзнака у оквиру исте лексеме, може се посматрати као последица могућности реинтерпретације семе лоше и склоност према сагледавању једне појаве или особине из двеју различитих, опречних перспектива - неповољне и повољне (нпр. злица), а ова појава није неуобичајена ни код неизведених речи (уп. лутка, лопов и сл.). Такође је могућа, мада релативно ретка, мотивација хипокористика пејоративом (уп. геак). Ову појаву посматрамо као потврду хомогености евалутивног система. У тим случајевима, међутим, детериорација не бледи у оној мери у којој се то дешава нпр. код маламелиоратива из групе физичких и естетских недостатака, већ се најчешће задржава у зони умерене еуфемизације (геја, геачић и сл.).

3.4. Аналогно деминутивима и аугментативима, који функционишу као антоними у домену квантитета (мало : велико), може се посматрати и однос између хипокористика и пејоратива (мило, блиско : немило, неблиско). Међутим, потоња, емотивно-аксиолошка значења, за разлику од типичних деминутива и аугментатива, јављају се у широком спектру укрштања и варирања значењских нијанси, условљених врстом суфикса, значењем основе и контекстом. Ова три основна елемента управљају моделовањем евалутивног значења као тродимензионалног концепта подложног саображавању намерама и потребама говорника. Зато сва четири поља која сачињавају евалутивни систем посматрамо кроз динамику њихових сталних, мањих или већих интерференција.

Као што квантитативни домен своју експресивност црпи из моћи реинтерпретације редуковања или повећања димензија, тако емотивно-аксиолошки пар хиn. - nеј. своје моделативне могућности заснива на метафорично схваћеној просторној удаљености од емотивног центра посматрача. Евалутивни систем, посматран у целини, почива на садејству двају примарно физичких концепата - димензије и удаљености, тј. емотивне дистанце: упркос антонимној сапостављености типичних представника, овај систем није оштро поларизован, већ представља динамичан, флексибилан континуум којим су обухваћени и различити, нетипични случајеви у којима се стичу наизглед неспојиве оцене. Тај невелики, „хибридни” ареал није уједначен, па тако у српском језику има доста негативних основа амелиоризованих деминутивним или хипокористичним суфиксима, али нема обрнутих случајева споја изразито позитивне оцене и аугментативно-пејоративног суфикса, а још мање је могућа пејорација хипокористичних образовања (осим као неуспешна творбена бравура, нпр. *секетина>сека и сл.). Ову асиметрију објашњавамо тиме што су семе драго, блиско стабилне, јер припадају вертикали добра, као стожеру позитивних вредности који језик и његови говорници чувају, и што - за разлику од семе 
лоше, која има различите варијетете - позитивне семе у овој позицији нису подложне реинтерпретацији. То значи да потенцијал реинтерпретације (у овом случају махом негативних) сема обезбеђује семантичку разноликост и vice versa. Последично, ова околност, с једне стране, доприноси очувању и стабилности концепта врлине, а с друге стране у хипокоризацији негативних основа видимо тенденцију да се позитивни ареал прошири емотивно-аксиолошком амелиорацијом негативних лексичких и/или творбених основа, и то управо на рачун социјално и индивидуално маркираних негативитета.

\section{ЛИТЕРАТУРА}

Бабић 1986: S. Babić, Tvorba riječi u hrvatskom književnom jeziku : nacrt za gramatiku, Zagreb: JAZU.

Белић 2000: А. Белић, О историјском развитку словенских деминутивних и амплификативних суфикса; Природа и порекло именица субјективне оцене, у: Упоредна словенска лингвистика (1), (Изабрана дела Александра Белића), Београд: Завод за уџбенике и наставна средства, 9-81.

Бјелановић 2006: Ž. Bjelanović, Hipokoristik kao oznaka za tvorbeni način i kao oznaka za vrstu značenja, Folia onomastica Croatica, 15, 1-14.

Вељковић Станковић 2011: Д. Вељковић Станковић, Речи субјективне оцене у настави српског језика и књижевности, Београд: Филолошки факултет.

Викторивна 2017: Р. Н. Вікторівна, Деминутивна енантиосемия в українській мові, Studia Linguistica 2017/11, 165-174.

Гpajc 1975: H. P. Grice, Logic and conversation. In: Cole, P., Morgan, J. (eds). Syntax and Semantics, 3. New York: Academic Press, 41-58.

Гранди и Кертвејеши 2015: N. Grandi, L. Körtvélyessy, Handbook of Evaluative Morphology, (Ed. by N. Grandi and L. Körtvélyessy), Edinburgh: Edinburgh University Press.

Дејвис 2007: B. L. Davies, Grice's Cooperative Principle: Meaning and rationality, Journal of Pragmatics 39, 2308-2331.

Драгићевић 2007: Р. Драгићевић, Лексикологија српског језика, Београд: Завод за уџбенике и наставна средства.

Клајн 2002: И. Клајн, Творба речи у савременом српском језику (део 2), Суфиксаиија и конверзија, Београд - Нови Сад: Завод за уџбенике и наставна средства, Институт за српски језик САНУ, Матица српска. 
Кликовац 2004: Duška Klikovac, Metafore u jeziku i mišljenju, Beograd: Biblioteka XX vek.

Лејкоф и др. ${ }^{2}$ 1991: G. Lakoff, J. Espenson, A. Schwartz. Master Metaphor List. Berkeley: University of California.

Макартур 1996: T. McArthur, Oxford Companion to the English Language, Oxford: Oxford University Press.

Окука 2008: M. Okuka, Srpski dijalekti, Zabreb: SDK Prosvjeta.

Ривелис 2008: Е. Ривелис, В глазу наблюдателя, или Антонимы ли рыба и мясо? Об энантиосемии и мнимых противоположностях, ScandoSlavica 54 (2008), 159-178.

Скализе 1984: S. Scalise, Generative Morphology, Dordrecht: Foris.

СМ 2001: Словенска митологија : енциклопедијски речник, редактори С. М. Толстој, Љ. Раденковић, Београд: ZEPTER BOOK WORLD.

Требјешанин 1991: Ж. Требјешанин, Представа о детету у српској култури, Београд: СКЗ.

Федорова 2011: К. В. Федорова, Эмоционально-оценочные производные в аспекте межславянской энантиосемии. Вестник Волгоградского государственного университета, Серия 2, Языкознание 2011. No 2 (14). 120-124.

Џурафски 1996: D. Jurafski, "Universal Tendencies in the Semantics of the Diminutive", Language Vol. 72, No. 3, 533-578.

Шипка 2002: М. Шипка, Енантиосемија у српском језику, у: Дескриптивна лексикографија стандардног језика и юене теоријске основе, 149-162.

Шмељов 2012: A. Shmelev, Cognitive and Communicative Sources of Enantiosemy, Proceedings of the 10th World Congress of the International Association for Semiotic Studies (IASS/AIS) Universidade da Coruña (España / Spain), 837-844.

\section{ИЗВОРИ}

PМC 1967-1976: Речник српскохрватскога књижевног језика, I-VI, Нови Сад: Матица српска.

РСАНУ 1959-2017: Речник српскохрватског књижевног и народног језика (т. I-XX), Београд: САНУ, Институт за српски језик.

PCJ 2011: Речник српскога језика (ур. Мирослав Николић), Нови Сад: Матица српска. 
СрпКор 2013: Корпус савременог српског језика (СрпКор), верзија СрпКор2013, Група за језичке технологије Универзитета у Београду, 2013.

Електронски / интернет извори: forum.b92.net $<1$. 12. 2014>, korisnaknjiga. com $<20.5 .2019>$, forum.krstarica.com $<20$. 10. 2019>, espreso.rs $<17$. 6. 2019>, slobodnaevropa.org <16.3.2006>, polja.rs [С. Тишма, Пролеће, одломак из прозе Quattro stagioni] <20. 9. 2019>, republika.rs $<21.8 .2017>$

\title{
ON HYPOCORISTIC MEANINGS OF APELLATIVE WITH A NEGATIVE EVALUATIVE SIGN OF FORMATIVE AND/OR LEXIC BASIS IN SERBIAN LANGUAGE
}

\begin{abstract}
Summary
In this paper we consider the dynamics of evaluative system which, as coherent and asymmetric continuum in Serbian is based upon the cooperation and interference of two primarily physical concepts - dimension and distance, or emotional distance. Considering semantic outcomes of hypocoristic formation of apellative with negative sign of formative and/or lexical bases, lined up into six topical groups leads to the following conclusions: (a) sememe of good (dear, close) as the central points of positive values kept by the language and its speakers, they are stable and unlike sememe bad which has different varieties, cannot be reinterpretated; (b) evaluative enantiosemy is the consequence of the reinterpretation potential of the sememe bad and/or the possibility for the insight into a phenomenon or a feature from two different, opposite prospects (eg. zlica - evil man); (c) hypocorization of negative bases is a tendency for enhancing positive areal with ameliorization and thus protecting the domain of virtue on account of socially and individually marked negativities.
\end{abstract}

Key words: evaluative system, Serbian language, word formation, malameliorativum, semantic derivation, hypocoristics, pejoratives, evaluative enantiosemy.

Dragana D. Veljković Stanković 